\title{
8
}
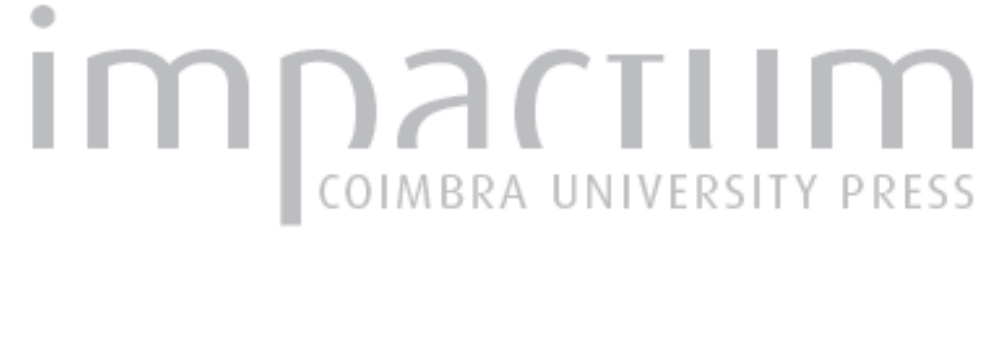

\section{Interactive stereoscopic visualization of Alberti architectural models}
Autor(es):
Araujo, Bruno; Mendes, Daniel; Fonseca, Fernando; Ferreira, Alfredo; Jorge, Joaquim; Costa, Eduardo; Figueiredo, Bruno; Coutinho, Filipe; Duarte, José Pinto

Publicado por: Editorial do Departamento de Arquitetura

URL

persistente:

URI:http://hdl.handle.net/10316.2/37233

DOI:

DOI:http://dx.doi.org/10.14195/1647-8681_5_5

Accessed : $\quad$ 26-Apr-2023 15:50:25

A navegação consulta e descarregamento dos títulos inseridos nas Bibliotecas Digitais UC Digitalis, UC Pombalina e UC Impactum, pressupõem a aceitação plena e sem reservas dos Termos e Condições de Uso destas Bibliotecas Digitais, disponíveis em https://digitalis.uc.pt/pt-pt/termos.

Conforme exposto nos referidos Termos e Condições de Uso, o descarregamento de títulos de acesso restrito requer uma licença válida de autorização devendo o utilizador aceder ao(s) documento(s) a partir de um endereço de IP da instituição detentora da supramencionada licença.

Ao utilizador é apenas permitido o descarregamento para uso pessoal, pelo que o emprego do(s) título(s) descarregado(s) para outro fim, designadamente comercial, carece de autorização do respetivo autor ou editor da obra.

Na medida em que todas as obras da UC Digitalis se encontram protegidas pelo Código do Direito de Autor e Direitos Conexos e demais legislação aplicável, toda a cópia, parcial ou total, deste documento, nos casos em que é legalmente admitida, deverá conter ou fazer-se acompanhar por este aviso. 


\section{Bruno Araujo, Daniel Mendes,}

Fernando Fonseca, Alfredo Ferreira,

Joaquim Jorge, Eduardo Costa,

Bruno Figueiredo, Filipe Coutinho,

José Pinto Duarte

Interactive Stereoscopic Visualization

of Âlberti Architectural Models 


\section{Introduction}

The technological advances that we have been witnessing in the last few years allowed the development of new and more interactive applications for all kinds of scenarios. A clear example are multitouch devices and depth sensors like Microsoft Kinect, which allows non-intrusive and inexpensive tracking of the user's body. In the visualization area, the vulgarization of $3 \mathrm{D}$ displays allows users to perceive imagery as it was getting out of the screen, providing a depth illusion. This technological advances motivate a fresh look at tabletop interfaces and to revisit on-and-above surface interaction techniques, in order to better support 3D direct manipulation and to aspire scenarios until now exclusive of science fiction.

Recently, innovative methods to use the space above the surface, in order to provide more natural ways of interacting with $2 \mathrm{D}$ tabletop content, have been proposed (Hilliges et al., 2010). Wilson et al. (2010) created metaphors to interact with different displays while capturing full body postures. Thus, users can interact on or above the surface with $2 \mathrm{D}$ content, or even between surfaces, using the body to transfer virtual content from one surface to the hand or to another surface, while moving their bodies in space.

Following the work of Hornecker (2008), who studied the effect of a multi-touch table in a museum of natural history, we exploited the aforementioned technological solutions to enhance the visitors experience in a museum exhibition. This exhibition was set out to present the architectural heritage left by the Renaissance artist, architect and author Leon Battista Alberti (1404-1472). The author, in his De re aedificatoria treatise, defined a strict shape grammar, without providing any images illustrating the architectural rules presented. Albeit difficult to interpret, this document greatly influenced several buildings spread across the world.

We developed a tabletop prototype that allows users to explore 3D virtual models of existing buildings in stereoscopy, as they were physical models lying above the tabletop. We also introduced the possibility to customize an entire model of a temple following the strict Alberti shape grammar.

\section{Hardware Setup}

To support our interactive prototype and provide a non-intrusive experience to the visitors of the exhibition, we developed an innovative setup. Our setup consists on a semi-immersive environment based on a stereoscopic multi-touch surface combined with three Microsoft Kinect depth cameras. These cameras track the user's head, hands and fingers above the $153 \times 88 \mathrm{~cm}$ tabletop. The head tracking enables a personalized perspective view of the content shown on the table. A video-projector under the table displays images on the surface at $120 \mathrm{~Hz}$ with a $1280 \times 720$ pixel resolution. A set of NVIDIA 3D Vision active shutter glasses guarantees the stereoscopic visualization.
1. User interacting with our prototype.

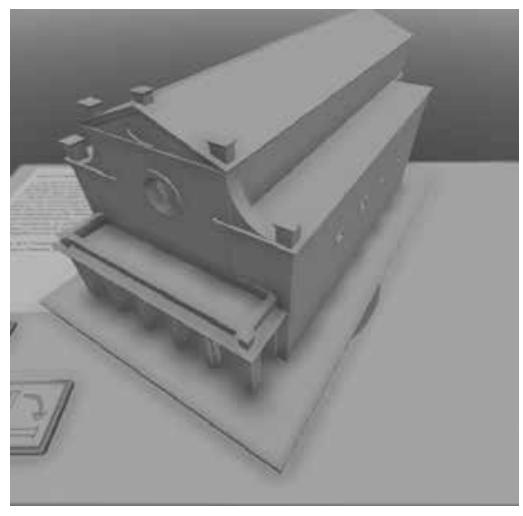

2. Virtual model of Espírito Santo de Évora, Portugal.

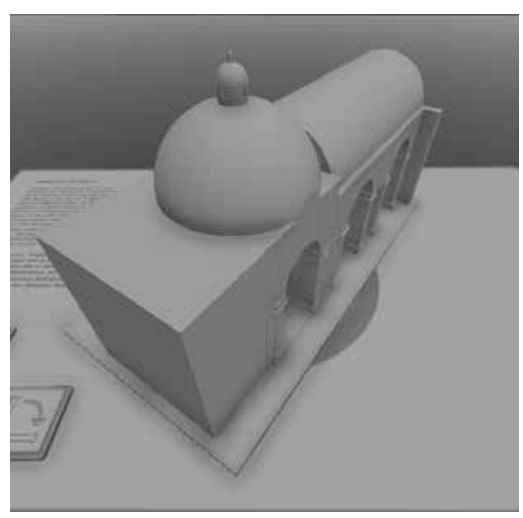

3. Virtual model of Eleven Thousand Virgins Chapel, Portugal. 


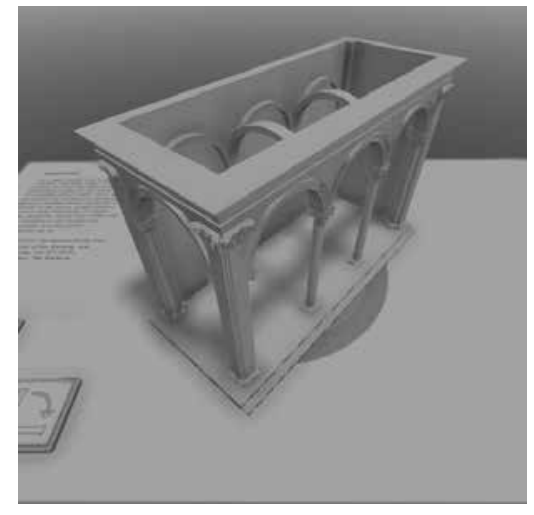

4. Virtual model of Loggia dei Lanzi, Italy.

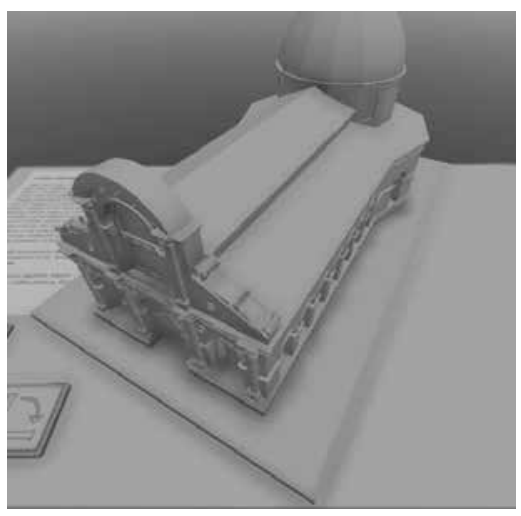

5. Virtual model of Malatestiano Temple, Italy.

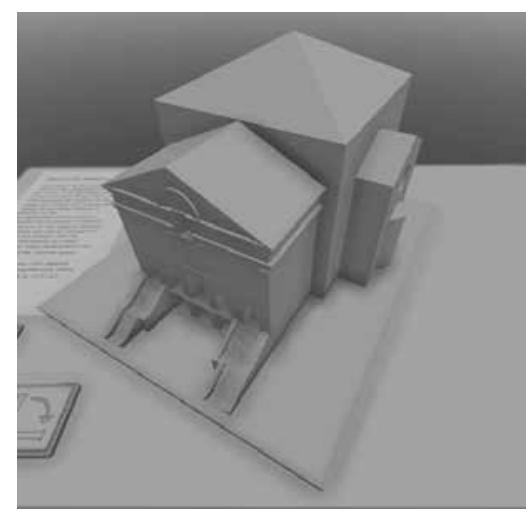

6. Virtual model of São Sebastião Church, Brazil.
Such setup allows rendering virtual objects such as if they were lying above the surface. The touch enabled surface, using Laser Light Plane technology, allows the interaction with virtual models, as shown in Figure 1 , and the hand tracking gives the hand position above the surface to highlight and provide more information about the displayed content.

\section{Visualization of Architectural Models}

With our semi-immersive environment, users can explore 3D virtual models of Alberti influenced buildings using both hands. To manipulate the content above the stereoscopic surface the visitor can use several touches to interact with each model at a time. Using one touch anywhere on the surface it is possible to move the model on the surface plane. Using a second touch, the user can rotate the model along the axis perpendicular to the surface and uniformly scale it, by changing the relative position between the two fingers. This is a direct adaptation of the well-known algorithm Rotate-N-Translate (Hancock et al., 2006), that is present in almost every multi-touch device nowadays.

Using this indirect touch approach we allow users to manipulate the virtual content along the surface without the need to bend his own body to be able to touch directly on the model to interact with it, avoiding body discomfort. By resorting to this interaction technique, we allow the exhibition visitors to explore five existent architectural models, which are portrayed in Figures 2 to 6 . While exploring a model, users can also rotate it 45 degrees around a horizontal axis, using a button on the table surface, making the front of the model directly facing his point of view. With this option we offer a better visualization of the model's front.

\section{Customizing Alberti Models}

In addition to the visualization of existing Alberti influenced buildings, we included a special model, which is a temple that supports three different types of customizations, accordingly to the shape grammar extracted from the De re aedificatoria treatise. Our prototype allows the customization of the temple columns, body and frontal parts independently and then, visualize all the parts together in a complete temple, as it is possible to see in Figure 7.

Visitors are able edit the size and height of the temple, the number of side chapels and its shapes and the back chapel (Figure 8). It is also possible to modify the front of the temple, allowing the customization of the number of columns, the colonnade and the pediment (Figure 9). Temple columns can also be customized, being possible to change the base, body, shaft and entablature (Figure 10). Along with all the different alternatives for the temple elements, our prototype displays a short descriptive text, containing relevant information about the model or a specific part history.

Both in the aforementioned editing modes and the visualization of the custom model, visitors can use his hands to point at specific model 
parts. Thanks to our novel setup, which tracks the user hands and fingers in the 3D space above the table, the user can use his forefinger to select each part of the model. The system, after detecting a collision between the finger end and the model, highlights that model part and shows an informative label, containing that part designation.

\section{Feedback from Visitors}

Our prototype has been on display at the Digital Alberti exhibition, from April 15th 2013 to June 20th 2013, in the Museum of Science of the Coimbra University. During this two months, we were able to observe and talk with some of the visitors that attended the exhibition and interacted with our prototype, and obtain some feedback.

In general, visitors considered that this kind of setups can make museum exhibitions more appealing and interactive. This was reinforced, given the fact that visitors could even create their own temple, allowing the interest raised by this architectural exhibition to be comparable to the one raised in a science exhibition, where visitors can witness "things happening", like making an air balloon fly with hot air. This comparison was actually made by a visitor who had previously attended a scientific exhibition that was present in another room of the museum at the same time.

We also noticed a vast interest from architects, who were fascinated not only with our prototype, but also with the possible impact it could have in their daily work. For example, such setup could make it easier and faster to present a rough model of a building to a client in a new and interactive way.

\section{Conclusions}

In order to enhance the museum experience, we developed a prototype taking advantages of the more recent technological advances, namely stereoscopic multi-touch displays and inexpensive and non-intrusive head and hands tracking using depth cameras. Our prototype allows a completely new and innovative approach for interacting with content, in the context of an architectural exhibition regarding the cultural heritage left by Leon Alberti.

While in traditional experiences visitors are only allowed to visualize physical models thought poster images or through protective glass, with our prototype they can directly interact with models of buildings. Visitors were allowed to explore five different architectural buildings with strong Alberti influence, but also to customize their own temple following the shape grammars of $D$ e re aedificatoria treatise. With this work, we reinforced the idea that it is possible to use virtual reality to improve museum experience for visitors, making it more appealing and interactive.

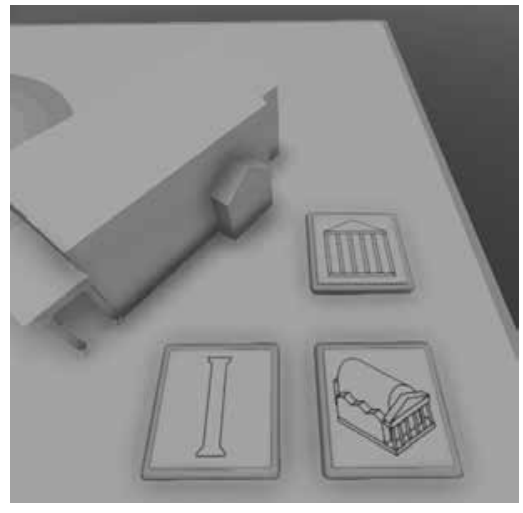

7. The three customizable elements of the temple.

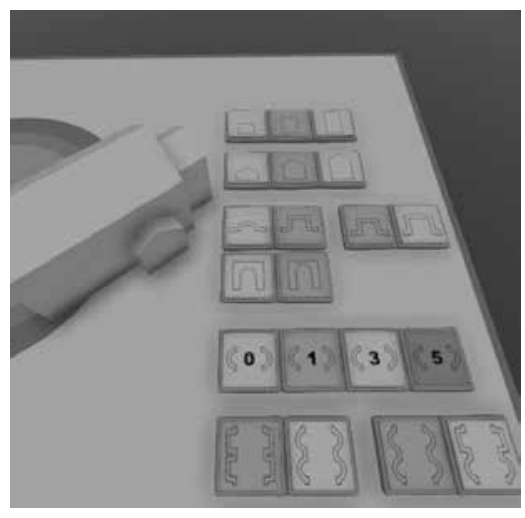

8. Customizable elements of the chapels.

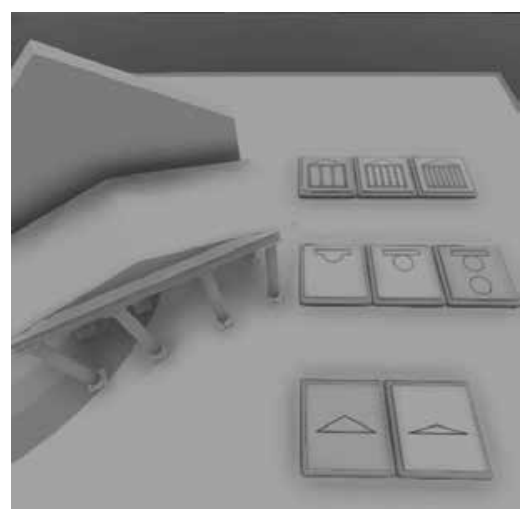

9. Customizable elements of the front of the temple. 


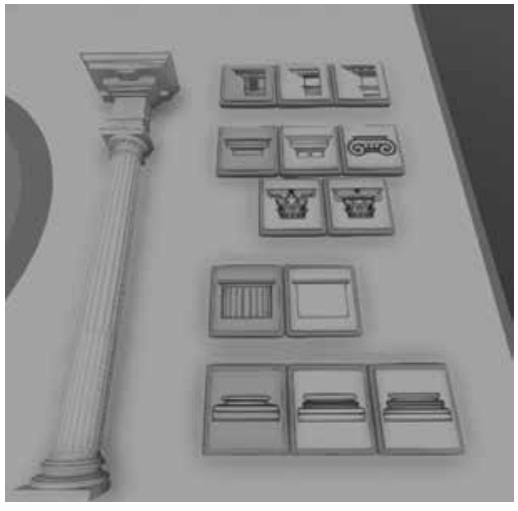

10. Customizable elements of the columns.

\section{Acknowledges}

This work was partially supported by the Portuguese Foundation for Science and Technology (FCT): doctoral grant SFRH/BD/91372/2012, project MIVis PTDC/EIA-EIA/104031/2008, Alberti Digital PTDC/ AUR-AQI/108274/2008, TECTON-3D PTDC/EEI-SII/3154/2012 and project PestOE/EEI/LAoO21/2013.

\section{References}

Hancock, M. S., Vernier, F. D., Wigdor, D., Carpendale, S., \& Shen, C. (2006). Rotation and translation mechanisms for tabletop interaction. In Horizontal Interactive Human-Computer Systems, 2006. TableTop 2006. First IEEE International Workshop on (pp. 8-pp). IEEE.

Hilliges, O., Butz, A., Izadi, S., \& Wilson, A. D. (2010). Interaction on the Tabletop: Bringing the Physical to the Digital. In Tabletops-Horizontal Interactive Displays (pp. 189-221). Springer London.
Hornecker, E. (2008). "I don't understand it either, but it is cool"-visitor interactions with a multi-touch table in a museum. In Horizontal Interactive Human Computer Systems, 2008. TABLETOP 2008. 3rd IEEE International Workshop on (pp. 113-120). IEEE.

Wilson, A. D., \& Benko, H. (2010). Combining multiple depth cameras and projectors for interactions on, above and between surfaces. In Proceedings of the 23nd annual ACM symposium on User interface software and technology (pp. 273-282). ACM. 